\title{
The Latest Petawawa Story
}

Because the Petawawa Forest Experiment Station is located within its boundaries, the federal government's announced spending cuts have had a profound effect on the Algonquin Section. Most readers will be aware by now of the impact of the spending cuts on the Canadian Forestry Service, and as the CIF response and action taken by the Executive and several Sections have been chronicled elsewhere in this issue, this report concerns itself solely with the story of Petawawa Forest Experiment Station.

On Thursday, September 7, the Station's Deputy Director, Dr. A. Carlisle, took a telephone message for Mr. R. F. Ackerman, the Director, who was away from the Station that afternoon. Mr. Ackerman called a staff meeting the next morning to relay that message. It was that the Petawawa Forest Experiment Station would be closed by the end of the fiscal year, March 31, 1979. The closure was to save the government $\$ 1.5$ million of the Station's \$2 million budget. Of the 78 man years allotted to the Station, 68 would be eliminated. The remaining $\$ 500,000$ and 10 positions would be retained by the Department of the Environment. The tree improvement and tree seed programs would be salvaged by the Canadian Forestry Service in some modified form. End of message.

Reaction was swift. Renfrew North-Nipissing East MP Len Hopkins met with area mayors and reeves on September 11. A resolution was drawn up strongly objecting to the proposed closure and requesting, through $\mathrm{Mr}$. Hopkins, a meeting with the Minister of the Environment and the President of the Treasury Board at the earliest opportunity.

Open house at P.F.E.S. was held the weekend of September 23 and 24. More than 2000 people visited the Station over the weekend, some from western Canada and various parts of the U.S.A. Remarks in the guest book complimented the Station's work, but many sharply criticized Ottawa.

By this time, opposition to the government's decision was mounting steadily. Both the Renfrew County Board of Education and the Renfrew Separate School Board urged the government to reconsider. The Renfrew County Board of Education had invested $\$ 58,000$ over the past two years in a comprehensive outdoor education program based on P.F.E.S. In the 1977-78 school year, 11,000 county students had visited the Station. Paul Boucher, then President of the CIF, added to the weight of opposition. His letter to Treasury Board is reproduced elsewhere in this issue. Thousands of letters were written to Members of Parliament from across the country. Letters appeared in newspapers almost daily. Several radio programs were devoted to the issue.

Mr. Hopkins and the local politicians met with the Minister of the Environment, Len Marchand, on September 29. That meeting was described in a local newspaper as "uncompromising". Mr. Hopkins reported that he left the meeting, at which were present the Deputy Minister, Blair
Seaborn, and several other high-ranking Department officials, feeling "angrier, more frustrated and more determined than ever to fight this thing". He also felt "we are fighting a wall of bureaucracy". "Surprisingly," Deep River Reeve, Bill Seddon, reported to Council, "both the Minister and the Deputy Minister reiterated that their main mission was to do scientific research". This was largely in response to the Board of Education's presentation concerning the educational value of P.F.E.S.

The one ray of hope seen at the meeting stemmed from a proposal made by Mr. Hopkins that the Forest Fire Research Institute and the Forest Management Institute be moved to P.F.E.S. "I feel very optimistic about the proposal," said Mr. Hopkins later. "The space is here (at P.F.E.S.), the housing is here and there is a lot of personnel already coming up here, so travel money could be saved". The Minister agreed to examine the proposal and a series of specific questions presented by the mayors and reeves. He promised to respond within 10 to 14 days.

Pressure on the government continued. On October 11, Prime Minister Trudeau and several other Ministers received copies of 372 pages of petitions with over 11,000 signatures opposing the closure of the Petawawa Forest Experiment Station. On October 12, Ray Metcalfe and Doug Champ of the Deep River Nature Group met with representatives of local churches, schools and community organizations to consider ways in which the Station's closure might be protested. A week later, an organization called "Forests for the Future" was created with membership from Pembroke to Deep River. This group's avowed intention is to support forestry research in Canada generally and in the Upper Ottawa Valley particularly. Its aim is to keep P.F.E.S. open and to create an on-going interest in forestry. Meanwhile, the promised deadline for a response from $\mathrm{Mr}$. Marchand had passed.

On October 26, Mr. Marchand announced that the federal government had reversed its decision to shut down the Petawawa Forest Experiment Station. Instead, the Forest Fire Research Institute and the Forest Management Institute will move from Ottawa to P.F.E.S. Mr. Marchand cited pressure from the residents of the Upper Ottawa Valley as well as from the forest industry across the country for the Government's change of heart. According to a press release from Environment Canada, the Petawawa consolidation will include an integrated research program emphasizing tree breeding, forest fire management systems, remote sensing and inventory techniques and energy from biomass. The consolidation will also provide some of the economies of scale. Overhead costs such as administration, water, power and road maintenance will be spread over a larger operation, thereby reducing the cost per research project. However, to achieve the Department's required 
budget reductions, according to the press release, employees in both Ottawa and Petawawa will have to be laid off. About 50 employees of the two institutes in Ottawa are expected to be released as well as about 18 from P.F.E.S., almost $1 / 4$ of the staff. The staff at P.F.E.S. did not receive a telephone message this time, but heard it over the media.

There has been one more event in the story of P.F.E.S. to the time of writing. A rally, organized by "Forests for the Future" was held on the Station on November 5. About 200 people were in attendance, including a large contingent from Ottawa and representatives from the major political parties. Although congratulations were expressed by many to those who helped keep P.F.E.S. open, dissatisfaction was very much in evidence - dissatisfaction with the decline in forestry research in particular and with government policy in general. Liberal MP Len Hopkins, Don Munro, the Progressive Conservative Environment Critic and MP Cyril Symes (NDP, Sault Ste. Marie) had to field many questions on these topics.

A. D. Hall, Executive Director of the Canadian Forestry Association, congratulated the people of the Upper Ottawa Valley for their effort to keep P.F.E.S. He called it the "finest expression of citizenship" we've had in forestry in a long time. He said the proposed reduction has focused attention on the forestry industry nationally and this attention is good.

Professor Paul L. Aird, University of Toronto, in his address to the rally described Petawawa as a "symbol of concern for the future", but criticized the Government for its lack of political will to care and to plan for the future of Canada. "Our trust in the federal government and its plans for the future were shattered with the recent announcement of plans to close P.F.E.S. In the past, the politicians and bureaucrats have found it easy to cut down support for the trees. In the last dozen years, they reduced the federal forest research effort to one half of its former status with little public outcry". Closing an entire Station was a major jolt, however, said Prof. Aird. He suggested that the decision was made by people who did not appreciate the Station's worth and did not anticipate the public outcry. He pointed out that the Minister has not visited P.F.E.S., nor the Deputy Minister, nor the Senior Assistant Deputy Minister, nor the Assistant Deputy Minister and so on. "Closing P.F.E.S. has symbolized the lack of political will to care and to plan for the future of Canada", stated Prof. Aird. His statement that what this nation needs is someone "to take Government, to take Cabinet and to shake it until the beast thinks green" met with enthusiastic applause from the audience. He called for Petawawa to be used "as a symbol to kindle a national reawakening of man's dependence on living nature and to stimulate a national willingness to maintain our biological resource base for all time".

In his speech to the Vancouver Section last December, Environment Minister Len Marchand told foresters that they will have to take their cause into the political arena if they want to see action on improved forest management. He said, "You have to get involved with the political process and make it work for you. A unified forestry constituency in Canada would, frankly, carry a lot of political clout. Get your hands on that clout and use it for the betterment of the forest resource and our economy - and for the people of Canada". $\mathrm{He}$ was absolutely right. The decision to close P.F.E.S. was purely political. It was political activity that changed that decision. The new decision, which still effectively reduces the Canadian Forestry Service, is in reality a political smoke screen. The story of P.F.E.S. should be a lesson to everyone concerned about forestry in Canada. Get together and get political!

B. D. Haddon

\section{Excerpts from the Honourable Len Marchand's Keynote Speech to the CIF-SAF Meeting}

- The theme of this meeting is "North American Forests: Gateway to Opportunity". It is, I think, an apt theme for several reasons. Canada and the United States are as one when it comes to forests. All of us here today are brought together because of a common interest: utilizing the North American forest resource to its best possible advantage.

- Throughout history, however, there have been those who recognized the forests as the living treasure they are. It is, in large part, because of people like these - people like all of you here today - that our two countries enjoy the large and diversified economies we now possess. Industrial giants that we are, there are still wooden shoes upon our feet.

- Our progress must be won through greater efficiency in terms of our exploitation of the forest resource. We must balance our wishes for greater yields from forestry with environmental realities which not only take into account our moments on the planet but those of all future generations. We can have more from our forests only if we proceed with prudence.

- To turn this objective into reality, there is a role to be played by all concerned parties - the forester, the politician, the industry and the public. There must be recognition among these people that their roles, although closely related, are not identical. I charge you - the foresters of North America - with the key catalytic role. You 